Article

\title{
What Drives the Participation of Renewable Energy Cooperatives in European Energy Governance?
}

\author{
Jale Tosun ${ }^{1,2, *}$, Laura Zöckler ${ }^{3}$ and Benedikt Rilling ${ }^{4}$ \\ ${ }^{1}$ Institute of Political Science, Heidelberg University, 69115 Heidelberg, Germany; E-Mail: jale.tosun@ipw.uni-heidelberg.de \\ ${ }^{2}$ Heidelberg Center for the Environment, 69120 Heidelberg, Germany \\ ${ }^{3}$ Bürgerwerke eG and Heidelberger Energiegenossenschaft eG, 69123 Heidelberg, Germany; \\ E-Mail: laura.zoeckler@posteo.de \\ ${ }^{4}$ Institute for International Research on Sustainable Management and Renewable Energy, Nuertingen-Geislingen \\ University, 72622 Nuertingen, Germany; E-Mail: benedikt.rilling@hfwu.de
}

* Corresponding author

Submitted: 13 October 2018 | Accepted: 2 January 2019 | Published: 28 March 2019

\begin{abstract}
What determines the willingness of renewable energy cooperatives (RECs) to strengthen their involvement in politics at the different levels of governments (local/regional, national, transnational)? We address this research question by using data from an original survey distributed to RECs in Germany. The descriptive analysis shows that the RECs are less willing to participate in energy governance at the EU/transnational level than at the national and especially the subnational level. Our analytical findings, first, show that the odds of RECs to participate in governance processes in the future are greater for those RECs that are already involved in such processes. Put differently, we find that engagement in energy governance is affected by path-dependence. Second, participation in subnational governance processes is determined by dissatisfaction with policy decisions taken at that level: the more dissatisfied the respondents, the more likely they are to exert influence in the future. For the Energy Union to realise its aim of incorporating a broader range of stakeholders, the European Commission must highlight the opportunity structure it provides for participating in governance processes.
\end{abstract}

\section{Keywords}

energy cooperatives; Energy Union; Germany; governance; renewable energy; survey data

\section{Issue}

This article is part of the issue "EU Energy Policy: Towards a Clean Energy Transition?", edited by Kacper Szulecki and Dag Harald Claes (University of Oslo, Norway).

(C) 2019 by the authors; licensee Cogitatio (Lisbon, Portugal). This article is licensed under a Creative Commons Attribution 4.0 International License (CC BY).

\section{Introduction}

In 2015, the European Commission published its Communication on the Energy Union, which calls for a transformation of Europe's energy governance system (European Commission, 2015). In 2016, a package of accompanying policy measures ("Winter Package") was presented (see Ringel \& Knodt, 2018). The Energy Union represents an ambitious project, which draws on the four pillars of EU energy policy: the functioning of the energy market, the security of supply, the promotion of energy efficiency and renewable energy, and the interconnection of en- ergy networks (see, e.g., Tosun, Biesenbender, \& Schulze, 2015). In addition, the Communication calls for speaking with one voice in international negotiations and assigns citizens an important role in the energy transition, that is a long-term structural change in energy systems to replace energy produced from non-renewable resources by renewable ones (see, e.g., Aklin \& Urpelainen, 2018; Cherp, Jewell, \& Goldthau, 2011; Fraune \& Knodt, 2017, 2018; Unnerstall, 2017; Verbong \& Loorbach, 2012). The European Commission's framework is remarkable, not least for its attempt to further strengthen the role citizens play in energy policy. The Communication that lays 
out the framework strategy states that the European Commission's vision of an Energy Union is one "with citizens at its core, where citizens take ownership of the energy transition" (European Commission, 2015, p. 2).

There exist two basic ways of interpreting this role assigned to citizens in the context of the energy transition. First, citizens can play an active role in energy transition by joining local renewable energy projects, among which renewable energy cooperatives (RECS) represent a particularly prominent form (Kalkbrenner \& Roosen, 2016; Moss, Becker, \& Naumann, 2015; Yildiz et al., 2015). RECs are based on business models where citizens jointly own and participate in renewable energy projects. RECs are characterised by open membership, democratic member control, economic participation through direct ownership, independence, cooperation among other cooperatives, and concern for the community. Second, citizens can play a more passive role by (not) accepting the implementation of local-level renewable energy projects such as the creation of wind parks (Fraune \& Knodt, 2017, 2018; Scherhaufer, Höltinger, Salak, Schauppenlehner, \& Schmidt, 2017).

In this study, we are interested in RECs as organisations that consist of citizens who join them voluntarily (see, e.g., Radtke, 2014). The literature on the determinants of citizens' willingness to join a REC is insightful. Kalkbrenner and Roosen (2016), for example, stress the importance of social norms, trust, environmental concern and community identity as important factors affecting the citizens' willingness to participate in RECs. We do not aim to contribute to that perspective. Instead, and in line with the aims and scope of this special issue, we consider RECS as collective actors and investigate their willingness to exert political influence. Put differently, we adopt a governance-oriented approach to RECs and examine their (potential) role in a broader institutional setting.

What determines the willingness of RECs to strengthen their involvement in politics at the different levels of governments (local/regional, national, transnational)? This is the research question that guides our analysis. The answer to this question provides important insights concerning the Energy Union's goal to strengthen the citizens' ownership of the energy transition, since citizen-based RECs play an important role in the energy transition. The European Environment Agency (2017, p. 13), for example, recognises RECs as key actors in energy governance. In Germany, RECs account for about $55 \%$ of the community-based energy sector (Kahla, Holstenkamp, Müller, \& Degenhart, 2017, p. 16), which makes them important actors in energy governance. In this context, we examine Germany-based RECs' willingness to participate in energy governance at the lo$\mathrm{cal} /$ regional, national, and transnational levels. We use data from a survey of the executive boards of RECs in Germany, collected in 2016/2017, that produced complete responses from 174 RECs.

The remainder of this study unfolds as follows. First, we provide some background information on how the
EU's energy governance has developed and to what extent citizens are now invited to participate in governance. Next, we turn to the European Federation of RECS (REScoop.eu) to show that an interest group representing RECs and their members has already been set up. We then develop a theoretical argument on the determinants of the willingness of RECs to exert political influence. The theory section is followed by the empirical analysis and a discussion of the findings. The final section then provides some concluding remarks and suggestions for future research.

Our empirical analysis reveals two important findings. First, a powerful predictor for RECs to exert influence in the future is their current involvement in governance processes. Second, dissatisfaction with policy decisions taken at the local level increases the odds of RECs to consider involvement in subnational governance processes. Concerning the other political levels, our analysis does not find that the level of dissatisfaction matters.

\section{What Role to Play for Renewable Energy Cooperatives in the Energy Union?}

In this study, we seek to offer an analysis of how RECs participate in European energy governance. We define energy governance as energy-related activities by state actors that is complemented by a multilevel and a multiactor process (Bazilian, Nakhooda, \& Van de Graaf, 2014, p. 219). In the case at hand, the multilevel system consists of state and non-state actors that are active at the local/regional, national, and transnational/European levels. The multi-actor component refers to the interaction between different types of state actors (e.g., federal governments and regional governments) as well as their interaction with non-state actors, such as nongovernmental organisations (NGOs) or citizen-based organisations such as RECs.

The point of departure for this analysis is the Energy Union, which the European Commission launched in February 2015 and which seeks to establish a new form of energy governance in the EU. The idea of founding an Energy Union was introduced by Donald Tusk when he was still Prime Minister of Poland, which aligns with the country's continued concerns over disruptions in energy supply (see Marcinkiewicz \& Tosun, 2015). The European Commission's $(2015$, p. 4) strategy for realising the Energy Union builds on the following five dimensions:

- Energy security, solidarity and trust;

- A fully integrated European energy market;

- Energy efficiency contributing to moderation of demand;

- Decarbonising the economy; and

- Research, innovation and competitiveness.

The mutual realisation of these five dimensions is expected to increase the EU's energy security, its sustainable development and competitiveness. The Communi- 
cation is remarkable in the sense that it frequently mentions citizens; in fact, citizens are often highlighted as the beneficiaries of the Energy Union. However, the European Commission (2015, p. 2) also stresses that it expects citizens to "take ownership of the energy transition". Consequently, in its section on the governance of the Energy Union, the communication stipulates the need to establish arrangements that facilitate "an energy dialogue with stakeholders to inform policy-making and support active engagement in managing the energy transition" (European Commission, 2015, p. 18). In other words, the Commission invites citizen-based organisations to become involved in energy governance.

The Energy Union is a new umbrella that brings together the elements of EU energy policy into an integrated approach, as well as a continuing process since, when the concept was adopted, it was still an "empty box" (Szulecki, Fischer, Gullberg, \& Sartor, 2016). A step towards the realisation of the Energy Union is the "Clean and Secure Energy for All Europeans"-Package or "Winter" Package published in November 2016, which also contains a proposal for the "Regulation on Governance of the Energy Union" (European Commission, 2016a, 2016b; for a discussion, see Ringel \& Knodt, 2018; Szulecki et al., 2016). Another important instrument is the annual progress reports prepared by the European Commission. In the most recent report, the European Commission (2017, p. 1) stated, "[n]ow is the time to mobilise all of society-citizens, cities, rural areas, companies, academia, social partners - to take full ownership of the Energy Union, take it forward and engage in developing the solutions of the future".

Despite mentioning the importance of citizen-based organisations in realising the Energy Union's goals, the strategic documents produced by the European Commission to date abstain from specifying what role citizens are exactly expected to play in the emerging governance arrangements. The lack of definitional clarity might prove problematic, since individual citizens or citizen-based organisations may not feel addressed if the Commission does not extend an invitation for their involvement and engagement.

Additionally, participation of citizen-based organisations, such as RECs, in energy governance may be inhibited by transaction costs (see Coase, 1988; Dahlmann, 1979; North, 1992; Williamson, 1981). Building on the original notion of transaction costs as associated with the work of Coase (1988), Tosun, De Francesco and Peters (2018) argue that policies, despite representing one specific form of an institution, can fail to lower transaction costs if they are ambiguous. Therefore, not only the existence, but also the design of institutions matters for stimulating efficiency (see also Coase, 1988). Applying this argument to the case of the Energy Union, the Commission is unlikely to attain its goal of increasing the involvement of stakeholders in energy governance if it does not detail how participation is to be facilitated. In other words, if RECs must invest to learn about their opportunities for participation, they may lack the capacity and/or willingness to become involved once they have gathered all necessary information. Thus, by defining the formats as precisely as possible, the Commission will be in a position to reduce the transaction costs and better stimulate stakeholder involvement in energy governance.

Szulecki et al. (2016) interpret the vagueness in the conceptualisation of the Energy Union differently. To these authors, the lacking details provide an opportunity structure for the various actor groups to participate in the process and to shape the institutional design in a way that reflects their own preferences. This perspective is equally plausible; but when looking at the different stakeholder groups, including RECs, they may lack the capacity and/or power to make such strategic use of the situation and to push for the realisation of their respective preferences concerning the institutional design of the Energy Union.

\section{European Federation of Renewable Energy Cooperatives}

In this section, before turning to the presentation of our theoretical argument, we discuss the most pertinent type of transnational networks active in the field of EU energy governance. Set up in 2013, REScoop.eu is the European Federation of RECs, which currently comprises about 1,500 RECs. The organisation offers a platform to citizens who engage in energy cooperatives and strives to aggregate and articulate their interests towards EU policy-makers. REScoop.eu recognises full and associated members; both types of members are involved in energy governance processes.

The federation is governed by a board of directors, which is elected by the general assembly for a four-year term, with the members being eligible for re-election. The board takes decisions related to policy, strategy and planning, as well as controls the budgets and supervises the coordinator. The general assembly comprises all members, including both full members and associate members. Full members have voting rights and are either individual RECs or national or regional federations. Associate members do not have voting rights and are nongovernmental organisations, associations, companies or individual citizens.

The organisational purpose of the federation is twofold: on the one hand, REScoop.eu provides guidance on best practices and seeks to stimulate learning processes among RECs; on the other, it formulates position documents with a view to impact policy-making. REScoop.eu also participates in the EU-funded Horizon 2020 project "Renewable Energy Cooperatives Mobilizing European Citizens to Invest in Sustainable Energy" (REScoop MECISE) as well as other Horizon 2020 projects (see Huybrechts, Creupelandt, \& Vansintjan, 2018), which shows how strongly the organisation is rooted in the EU.

Table 1 gives an overview of REScoop.eu members, broken down into full and associate members. It is im- 
portant to remember that many individual energy cooperatives are members of REScoop.eu through their national federation, that is, they are represented indirectly. Among the full members are national and regional federations of RECs and individual cooperatives. When examining the table, it becomes apparent that German RECs are well represented in the network through the German Cooperative and Raiffeisen Confederation (DGRV). According to the most recent survey (see Fischer \& Wetzel, 2018), the number of RECs in Germany equalled 928 in 2015, whereas the DGRV (2017) represented 862 RECs by the end of 2017. Although both take into account new foundations since 2006 please note that the figures from Fischer and Wetzel (2018) and DGRV (2017) are not fully comparable due to different timescales and different accounting methods. We cannot, for instance, preclude that the DGRV (2017)-although only a negligible share-takes non-REC cooperatives into account. From correspondence with REScoop.eu (Creupelandt, 2018, personal communication), we conclude that all RECs represented by the DGRV are also represented in REScoop.eu. If we consider the number of RECs identified by Fischer and Wetzel (2018), we can still confirm that more than $90 \%$ of the German energy cooperatives are-at least indirectly-represented in this particular network. Both are impressive numbers and suggest that it is worth looking at RECs in Germany in detail (see also Klagge \& Meister, 2018).

Another country that is well represented in the network is the United Kingdom, followed by energy cooperatives in the Netherlands, Belgium, Spain, Italy, and Switzerland. Croatia, Denmark, France, Greece, Ireland, and Portugal participate in the REScoop.eu by means of individual energy cooperatives. Turning to the three associate members, these are the EMES research network of university research centres and individual researchers on social enterprise in Belgium, ALlenergy (an energy agency) in the United Kingdom, and BBEn (a citizen energy alliance) in Germany.

In the following sections, we will concentrate on German RECs for the following three reasons. First, RECs exist in large numbers in Germany (Kahla et al., 2017). Second, RECs represent an "important building block in the energy transition in Germany" (Yildiz et al., 2015, p. 59). Third, as shown above, RECs in Germany are widely represented in transnational networks, which suggests that we can draw particularly valuable insights concerning the RECs' willingness to participate in EU energy governance.

\section{Theoretical Considerations and Hypotheses}

The research interest of this study concerns the conditions under which RECs become willing to engage in energy governance at the subnational, national and EU levels. We assume RECs-similar to other strategic actorsto be sensitive to the expected costs and benefits of becoming involved in governance arrangements. In most cases, RECs are managed by volunteers with limited capacity (see e.g., Herbes, Brummer, Rognli, Blazejewski, \& Gericke, 2017; Müller et al., 2015; Radtke, 2014), which make considerations of costs and benefits particularly pertinent for explaining the (intended) behaviour of RECs. Consequently, RECs are likely to become involved in governance arrangements if the expected benefits exceed the expected costs. The benefits of participating in energy governance for RECs primarily consist of the possibility to influence policy decisions in such a way that renewable energy projects can be implemented more easily and under more favourable conditions. Since the Energy Union is currently under construction (see Ringel \& Knodt, 2018), we are interested in the determinants of future involvement in energy governance rather

Table 1. Overview of REScoop.eu members, 2018.

\begin{tabular}{|c|c|c|c|}
\hline & \multicolumn{2}{|c|}{ Full members } & \multirow[b]{2}{*}{ Associate members } \\
\hline & Federations & Individual & \\
\hline Belgium & 25 & 5 & 1 \\
\hline Croatia & & 1 & \\
\hline Denmark & & 1 & \\
\hline France & & 3 & \\
\hline Germany & $850^{*}$ & 2 & 1 \\
\hline Greece & & 3 & \\
\hline Ireland & & 2 & \\
\hline Italy & 20 & 4 & \\
\hline Netherlands & 56 & 1 & \\
\hline Portugal & & 1 & \\
\hline Spain & 17 & 5 & \\
\hline Switzerland & 20 & & \\
\hline United Kingdom & 198 & 3 & 1 \\
\hline
\end{tabular}

Notes: Own elaboration based on https://www.rescoop.eu/members (last access 6 October 2018). *Note the particularity for Germany that RECs are represented in REScoop.eu through their membership in the DGRV. According to the DGRV (2017), by the end of 2017, there existed 862 RECs in Germany. To avoid confusion, in the table we only report the figures retrieved from the website of REScoop.eu. 
than current engagement. Further, our analysis examines the three levels at which RECs could become involved, namely the subnational, national and EU levels.

The current level of engagement is, however, an important factor for explaining future activities-as studies on organisational behaviour rooted in historical institutionalism also argue (see Thelen, 1999). We expect those RECs that are already active to be more likely to participate in governance arrangements in the future as well. This expectation is informed by the variation in the transaction costs (Coase, 1988), which comprise costs related to searching and processing information, bargaining, and monitoring and enforcement (Dahlman, 1979, p. 148). By reducing transaction costs, for example by creating appropriate institutions (North, 1992), decision-making can become more efficient (Williamson, 1981). The transaction costs should be low for RECs that already participate in governance at a given political level, but higher for RECs that do not participate in governance arrangements at the same political level. In other words, investing once in gathering information about the existence and functioning of governance arrangements generates "increasing returns" (Pierson, 2000), which explains why RECs that already participate in energy governance are also more likely to participate in it in the future. This reasoning paves the way for our first hypotheses:

H1a: RECs that currently participate in governance arrangements at the subnational level are more likely to participate in such governance arrangements in the future.

$\mathrm{H} 1 \mathrm{~b}$ : RECs that currently participate in governance arrangements at the national level are more likely to participate in such governance arrangements in the future.

$\mathrm{H} 1 \mathrm{c}$ : RECs that currently participate in governance arrangements at the EU level are more likely to participate in such governance arrangements in the future.

The first hypothesis focuses on the transaction costs associated with participating in governance arrangements but does not take into account the fact that RECs can choose between multiple venues for their engagement in EU energy policy, that is, the subnational, national and transnational/EU levels. To formulate hypotheses, we can think of RECs as advocacy organisations that strategically select one or more venues for participating in energy governance (see Holyoke, Brown, \& Henig, 2012). The EU's multilevel system offers multiple points of access or opportunity structures (Princen \& Keremans, 2008) to RECs that are willing to participate in energy governance. Some RECs should have the capacity (i.e., funding and personnel; Eising, 2007) to be active at the various levels of the EU political system (Eising, 2008), whereas RECs with limited capacity must choose in which institutional level they want to participate in governance activities, if any. While we need to take capacity into account when fitting our estimation models, this variable cannot explain which of the three levels availablesubnational, national, transnational/EU-will be chosen by RECs.

A variable that has a greater potential for explaining the selection of a political venue is satisfaction. According to Hadjar and Beck (2010), political interest and participation is generated by dissatisfaction with policy decisions. Following this reasoning, we expect that RECswhich are generally limited in their resources-will select the political level with which they are unsatisfied for participating in governance processes. A similar argument is put forward by Pleines (2010, p. 241), who explains that civil society organisations from Central and Eastern Europe are heavily involved in governance processes at the EU level since they are dissatisfied with EU policies. Drawing from these considerations put forward in different literatures (interest group behaviour and political participation), we formulate the following hypotheses:

H2a: RECs that are dissatisfied with policy decisions at the subnational level are more likely to participate in governance activities at that level in the future.

$\mathrm{H} 2 \mathrm{~b}$ : RECs that are dissatisfied with policy decisions at the national level are more likely to participate in governance activities at that level in the future.

H2c: RECs that are dissatisfied with policy decisions at the EU level are more likely to participate in governance activities at that level in the future.

\section{Data and Methods}

This analysis is based on an original dataset constructed by using data from an online survey administered between November 2016 and March 2017. Drawing from the website www.energiegenossenschaftengruenden.de, we identified a total number of 762 RECs to form the population, which left us with a figure smaller than the 928 RECs identified by Fischer and Wetzel (2018). Of the 762 RECs, we could only find contact details in the form of email addresses for 616. In November 2016, we contacted the executive board members of these RECs via email and invited them to participate in the online survey. The RECs were contacted a second time in December 2016 and a third time in January 2017 to remind them of the survey and to re-extend our invitation. Of the 616 RECs to receive an email invitation, 174 management board representatives completed the online survey for their REC, which corresponds to a response rate of $28 \%$. It is important to remember that the data collected reflects the perspective of the REC executive board members only and that asking the individual members could have produced different answers (Holstenkamp \& Kahla, 2016). Since we are interested in strategic decisions made by RECs, approaching the executive board members appeared an adequate strategy. The 
responses were treated anonymously according to the relevant German data protection laws.

Before fielding the online survey programmed in Lime Survey, it was pretested in September and October 2016 with 10 students and three selected representatives of two local RECs for checking the comprehensiveness, meaningfulness and length of the questions. While we did not receive any critical response regarding the length of the questionnaire, we changed the wording of some questions to make them more intuitive in light of the feedback we received. For instance, while we are interested in participation in governance processes, the pretest of the survey questionnaire revealed that "exerting influence" is the proxy for this construct, which is best understood by the respondents.

In what follows, we analyse the following questions as outcome variables, which comprise the response categories "yes", "no", "don't know" as well as "no response":

- Is your cooperative intending to exert influence at the community level in the future?

- Is your cooperative intending to exert influence at the regional level in the future?

- Is your cooperative intending to exert influence at the federal level in the future?

- Is your cooperative intending to exert influence at the European level in the future?

- Is your cooperative intending to exert influence at the transnational level in the future?
We deleted the latter two response categories ("don't know" and "no response") to construct a binary outcome variable that takes the value 1 if a level was mentioned and 0 if not mentioned. We combined the community level and the regional level to generate the outcome variable Subnational Future (1 if either or both were mentioned, 0 if not). The question on the federal level is the second outcome variable National Future. For the third outcome variable, EU/transnational Future, we combined the European and the transnational levels ( 1 if either or both were mentioned, 0 if not).

Table 2 presents the response patterns we obtained for the intention to participate at the various levels - subnational, national, and EU/transnational-in the future (outcome variables) and the current engagement (one of the focal explanatory variables, which is also binary). There are several observations in the table worth noting. The first one refers to the low share of respondents $(12 \%)$, indicating that they currently exert influence at the EU/transnational level. Recalling Table 1 and the information provided in section 3 (that German RECs are automatically members of REScoop.eu), the response pattern suggests that most RECs are not aware of their potential to exert influence at the EU/transnational level. This mismatch between the membership in REScoop.eu and the RECs awareness of it can be explained by their indirect membership through the DGRV. If they exert influence, with most RECs (72\%) it is at the subnational level, followed by the national level with $27 \%$. Note that the respondents could indicate multiple political levels at which they exert influ-

Table 2. Overview of current and future influence by German RECs.

\begin{tabular}{|c|c|c|c|}
\hline Variables & $\begin{array}{l}\text { No }(=0) \\
\text { Absolute } \\
\text { numbers } \\
\text { Percentage }\end{array}$ & $\begin{array}{l}\text { Yes }(=1) \\
\text { Absolute } \\
\text { numbers } \\
\text { Percentage }\end{array}$ & Descriptive statistics \\
\hline Subnational Current & $\begin{array}{l}48 \\
27.59 \%\end{array}$ & $\begin{array}{l}126 \\
72.41 \%\end{array}$ & $\mathrm{~N}=174$, Mean $=0.724$, Standard Deviation $=0.448$ \\
\hline Subnational Future & $\begin{array}{l}25 \\
14.37 \%\end{array}$ & $\begin{array}{l}149 \\
85.63 \%\end{array}$ & $\mathrm{~N}=174$, Mean $=0.856$, Standard Deviation $=0.352$ \\
\hline National Current & $\begin{array}{l}119 \\
73.01 \%\end{array}$ & $\begin{array}{l}44 \\
26.99 \%\end{array}$ & $\mathrm{~N}=163$, Mean $=0.270$, Standard Deviation $=0.445$ \\
\hline National Future & $\begin{array}{l}67 \\
47.86 \%\end{array}$ & $\begin{array}{l}73 \\
52.14 \%\end{array}$ & $\mathrm{~N}=140$, Mean $=0.521$, Standard Deviation $=0.501$ \\
\hline EU/transnational Current & $\begin{array}{l}153 \\
87.93 \%\end{array}$ & $\begin{array}{l}21 \\
12.07 \%\end{array}$ & $\mathrm{~N}=174$, Mean $=0.121$, Standard Deviation $=0.327$ \\
\hline EU/transnational Future & $\begin{array}{l}134 \\
77.01 \%\end{array}$ & $\begin{array}{l}40 \\
22.99 \%\end{array}$ & $\mathrm{~N}=174$, Mean $=0.230$, Standard Deviation $=0.422$ \\
\hline Current & $\begin{array}{l}47 \\
27.01 \%\end{array}$ & $\begin{array}{l}127 \\
72.99 \%\end{array}$ & $\mathrm{~N}=174$, Mean $=0.723$, Standard Deviation $=0.445$ \\
\hline Future & $\begin{array}{l}24 \\
13.79 \%\end{array}$ & $\begin{array}{l}150 \\
86.21 \%\end{array}$ & $\mathrm{~N}=174$, Mean $=0.862$, Standard Deviation $=0.346$ \\
\hline
\end{tabular}

Note: The numbers reported refer to the 174 RECs that completed the survey; incomplete and partly completed surveys were disregarded. 


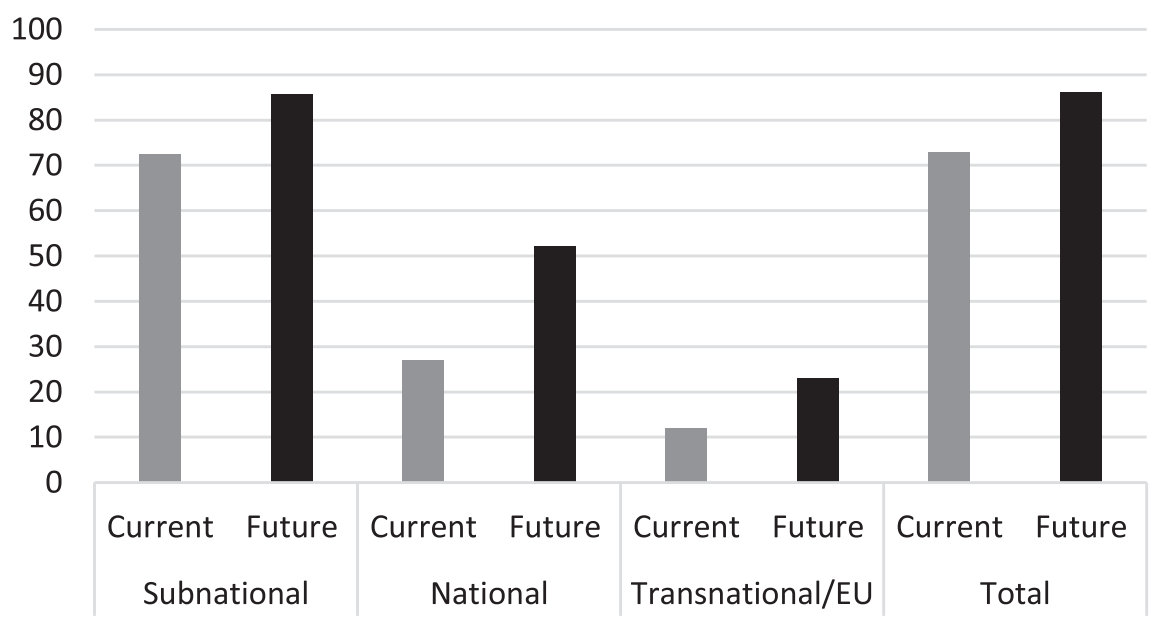

Figure 1. Bar graph of the current and future influence of RECs.

ence. Regarding future influence, it is again the subnational level where $86 \%$ of the RECs intend to become active, followed by the national level (52\%) and then the EU/transnational level (23\%). Figure 1 offers a visualisation of the numbers reported in table 2 .

The second set of focal explanatory variables refers to the degree of dissatisfaction with renewable energy policy decisions at the subnational, national and EU levels. The response categories range from 4 (= very unsatisfied) to 1 (= very satisfied). We treated "don't know"replies as missing data.

In addition to the two sets of focal explanatory variables, current influence and dissatisfaction with policy decisions taken at the various political levels, we include a number of control variables. As discussed in the theory section, the literature on interest group behaviour suggests that capacity plays an important role (see, e.g., Eising, 2007). Therefore, the RECs' willingness to participate in governance processes and exert influence should depend on their Age (in years; reference year $=2017$ ), which is a rough indicator of how established and professional they are. Membership Size, in eight categories, 1 (smaller than 50) to 8 (greater than 1000), is equally important for assessing the capacity of RECs, since we expect RECs with a greater membership size to benefit from more personnel and to be in a better position to seek influence in the future. Likewise, the RECs' Invest- ment volume (ranging from $1=$ below 200.000 EUR to 4 = above 3 million EUR) is an indicator of their organisational capacity. Furthermore, we need to control for the self-understanding of the individual RECs, in the sense of whether they seek Political Engagement at all ( 1 = yes, $0=$ no) and whether influencing political decisions is the most important goal $(1=$ yes, $0=$ no) of the respective REC. Thus the control variables relate to capacity and Political Ambition of the RECs, which aligns with the literature on interest group advocacy in multilevel systems (Eising, 2008). Table 4 reports the summary statistics for the individual explanatory variables, excluding the first set of focal explanatory variables as they are already presented in Table 2. The wording of the questions used for the operationalisation of all variables can be found in Table A3 (Annex).

In the next section, we will estimate logistic regression models for the first two outcome variables. Since we cannot estimate conventional logistic regression models for future engagement at the EU level due to the markedly unequal distribution of the values, the chosen method is penalised maximum likelihood estimations as put forth by Firth (1993). Observing very few events of interest is not a problem per se, and, in many cases, estimating regular logistic regression models does not produce biased results. With the data at hand, however, the problem of rare events is paired with a small

Table 4. Descriptive statistics.

\begin{tabular}{|c|c|c|c|c|c|}
\hline Variable & $\mathrm{N}$ & Mean & Std. Dev. & Min & Max \\
\hline Subnational Dissatisfaction & 171 & 2.611 & .703 & 1 & 4 \\
\hline National Dissatisfaction & 174 & 3.552 & .650 & 1 & 4 \\
\hline EU Dissatisfaction & 156 & 3.391 & .658 & 1 & 4 \\
\hline Age & 174 & 5.914 & 2.447 & 1 & 22 \\
\hline Membership & 173 & 3.497 & 1.662 & 1 & 8 \\
\hline Investment & 172 & 2.459 & 1.099 & 1 & 4 \\
\hline Political Engagement & 174 & .937 & .244 & 0 & 1 \\
\hline Political Ambition & 174 & .086 & .282 & 0 & 1 \\
\hline
\end{tabular}


number of observations. Since estimates based on unconditional maximum likelihood functions tend to become inaccurate when confronted with a small number of cases, we need to implement the correction offered by Firth's estimator.

\section{Presentation and Discussion of the Results}

We now turn to the empirical testing of the hypotheses put forward in Section 4. Table 5 presents the findings of the logistic regressions (estimated according to Firth's approach for the third outcome variable). The table presents two models per outcome variable: one variable with the focal explanatory variables only (Basic) and a second one that includes the control variables (Full). The models differentiate between the subnational (Sub), national (Nat), and EU/transnational (EU) levels. For a better interpretation of the estimation results, odds ratios are reported. Odds ratios greater than 1 indicate that the odds for a given outcome are higher, whereas odds ratios smaller than 1 indicate that the odds are lower. As we can infer from the table, the odds of RECs to exert influence at the subnational level is 65 times higher for RECs that already exert influence at that level. For the national level, the odds are 37 and 50 times higher for
RECs to exert influence at that level. Likewise, current exertion of influence at the EU level increases the odds for future engagement at that level by 74 and 71 times. Consequently, the empirical findings support hypotheses $\mathrm{H} 1 \mathrm{a}-\mathrm{H} 1 \mathrm{c}$. Regardless of the respective political level, the current engagement in governance arrangement is a strong predictor of future engagement.

Turning to the second set of explanatory variables, dissatisfaction with policy decisions taken at the subnational level increases the odds of RECs to seek influence in the future at the same political level, which supports $\mathrm{H} 2 \mathrm{a}$. Figure 2 presents the predicted probabilities for the RECs to answer that they intend to exert influence at the subnational level in the future and how the probability changes with the degree of satisfaction with subnational policy decisions. The estimates are based on the models Sub-Basic and Sub-Full in Table 5. While the probability that a REC will seek to exert influence at the subnational level in the future begins with .62 (Sub-Basic) and .70 (Sub-Full), respectively, it increases with growing dissatisfaction with the policy decisions taken at that level. The probabilities vary for the first three values of dissatisfaction for the two model specifications, but converge with values greater than 2 . It should also be noted that, for the values smaller than 2 , the $95 \%$ confidence inter-

Table 5. Results of the logistic regression models for the three outcomes variables.

\begin{tabular}{|c|c|c|c|c|c|c|}
\hline & Sub-Basic & Sub-Full & Nat-Basic & Nat-Full & EU-Basic & EU-Full \\
\hline Subnational Current & $\begin{array}{l}64.74 \\
(54.46)^{* * *}\end{array}$ & $\begin{array}{l}64.43 \\
(59.92)^{* * *}\end{array}$ & & & & \\
\hline National Current & & & $\begin{array}{l}36.98 \\
(28.50) * * *\end{array}$ & $\begin{array}{l}49.76 \\
(41.80)^{* * *}\end{array}$ & & \\
\hline EU/transnational Current & & & & & $\begin{array}{l}74.15 \\
(64.79)^{* * *}\end{array}$ & $\begin{array}{l}71.12 \\
(67.48)^{* * *}\end{array}$ \\
\hline Subnational Dissatisfaction & $\begin{array}{l}3.72 \\
(1.94)^{* *}\end{array}$ & $\begin{array}{l}3.49 \\
(1.95)^{* *}\end{array}$ & $\begin{array}{l}1.14 \\
(0.37)\end{array}$ & $\begin{array}{l}1.46 \\
(0.54)\end{array}$ & $\begin{array}{l}1.46 \\
(0.52)\end{array}$ & $\begin{array}{l}1.62 \\
(0.65)\end{array}$ \\
\hline National Dissatisfaction & $\begin{array}{l}1.39 \\
(0.84)\end{array}$ & $\begin{array}{l}1.28 \\
(0.83)\end{array}$ & $\begin{array}{l}1.55 \\
(0.68)\end{array}$ & $\begin{array}{l}2.18 \\
(1.10)\end{array}$ & $\begin{array}{l}0.93 \\
(0.46)\end{array}$ & $\begin{array}{l}1.09 \\
(0.58)\end{array}$ \\
\hline EU Dissatisfaction & $\begin{array}{l}0.76 \\
(0.47)\end{array}$ & $\begin{array}{l}0.83 \\
(0.55)\end{array}$ & $\begin{array}{l}0.83 \\
(0.35)\end{array}$ & $\begin{array}{l}0.78 \\
(0.36)\end{array}$ & $\begin{array}{l}1.31 \\
(0.63)\end{array}$ & $\begin{array}{l}1.22 \\
(0.58)\end{array}$ \\
\hline Age & & $\begin{array}{l}1.18 \\
(0.20)\end{array}$ & & $\begin{array}{l}0.93 \\
(0.12)\end{array}$ & & $\begin{array}{l}0.88 \\
(0.12)\end{array}$ \\
\hline Membership & & $\begin{array}{l}0.93 \\
(0.25)\end{array}$ & & $\begin{array}{l}0.73 \\
(0.14)^{*}\end{array}$ & & $\begin{array}{l}0.74 \\
(0.15)\end{array}$ \\
\hline Investment & & $\begin{array}{l}0.85 \\
(0.32)\end{array}$ & & $\begin{array}{l}2.30 \\
(0.74)^{* * *}\end{array}$ & & $\begin{array}{l}1.50 \\
(0.45)\end{array}$ \\
\hline Political Engagement & & $\begin{array}{l}1.12 \\
(1.10)\end{array}$ & & $\begin{array}{l}3.56 \\
(4.39)\end{array}$ & & $\begin{array}{l}3.05 \\
(4.52)\end{array}$ \\
\hline Political Ambition & & - & & $\begin{array}{l}1.90 \\
(1.94)\end{array}$ & & $\begin{array}{l}0.63 \\
(0.80)\end{array}$ \\
\hline Cases & 154 & 140 & 123 & 121 & 154 & 151 \\
\hline $\mathrm{AIC}$ & 76.97 & 82.01 & 129.94 & 129.09 & 109.59 & 103.62 \\
\hline
\end{tabular}

Notes: The table reports odds ratios; the models for the EU are estimated with the Firth correction; in Model Sub-Full, the odds ratios for political ambition are omitted from the estimation routine because of this variable's dependence on other variables in the model. Table A6 in the Annex contains a fourth model that uses the total share of positive replies by REC executive board members regardless of the political level as an outcome variable. $* \mathrm{p}<0.10,{ }^{* *} \mathrm{p}<0.05 ;{ }^{* * *} \mathrm{p}<0.01$. 


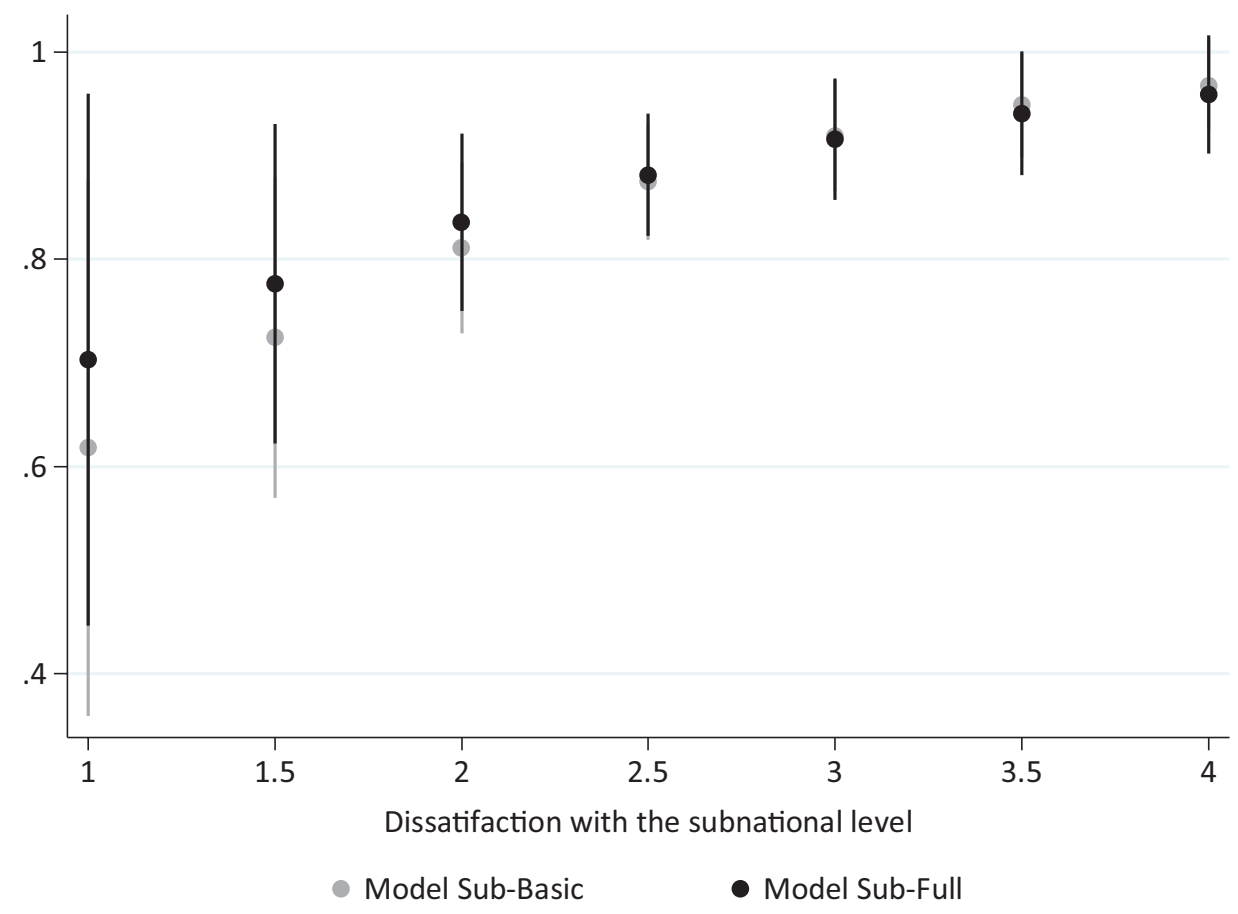

Figure 2. Predicted probabilities for future engagement at the subnational level with $95 \%$ confidence intervals for the models Sub-Basic and Sub-Full.

vals are also comparatively great, which can be explained by the smaller number of observations for these categories. Alternative specifications of the estimation models reported in Tables A7 and A8 (Annex) confirm the importance of dissatisfaction with the subnational level for the RECs' intentions of becoming active in governance arrangements in the future. For the other political levels, we do not find any empirical support in the models and therefore must reject hypotheses $\mathrm{H} 2 \mathrm{~b}-\mathrm{H} 2 \mathrm{c}^{1}{ }^{1}$

With regard to the control variables, it is worth noting that they do not produce significant odds ratios. Only in Model Nat-Full is the odds ratio significant at the $10 \%$ level and smaller than 1, indicating that a greater membership size reduces the odds of exerting influence in the future at the national level. When inspecting the Akaike Information Criterion (AIC), we can also see that the control variables do not always improve the fit of the models. Since smaller AIC values indicate a better fit, we can note that Model Sub-Basic performs better than Model SubFull. For the second outcome variable, the improvement in the model fit is minimal, but for the third outcome variable the control variables indeed improve the model fit.

To summarise, we can conclude that the empirical findings support hypotheses $\mathrm{H} 1 \mathrm{a}-1 \mathrm{C}$ and $\mathrm{H} 2 \mathrm{a}$. The empirical findings corroborate the importance of the current engagement in governance arrangements for future engagement as well as the mobilisation power of dissatisfaction with policy decisions taken at the subnational level for the odds of RECs to consider exerting influence in the future. We consider both findings relevant for the
European Commission's intention of increasing the participation of stakeholders in energy governance in the context of the Energy Union. First, we observe a pathdependent process, which may lead to a selective participation of (German) RECs in EU energy governance. Second, it is dissatisfaction (at the subnational level) that mobilises RECs rather than satisfaction, which also suggests that (German) RECs will consider carefully whether to become involved in energy governance (at the subnational level).

\section{Conclusions}

With its commitment to form an Energy Union, the EU offers an opportunity structure for stakeholder engagement and a way to decentralise energy governance. The descriptive part of this analysis has shown that an important stakeholder group in Germany-RECs-is currently only marginally involved in energy governance, mostly at the subnational level. This suggests that the German RECs' willingness and/or capacity to become involved in energy governance at the EU/transnational level is limited. This finding is plausible, considering that most members of RECs are active on a voluntary basis and that becoming involved with energy governance, even at the local level, entails considerable effort and can easily overwhelm volunteers. Research has shown that the management duties of executive REC board members are increasing, which limits their capacity for other activities (see e.g., Herbes et al., 2017; Müller et al., 2015;

\footnotetext{
${ }^{1}$ Table A8 (Annex) reports models that contain even fewer variables to check the robustness of the findings for the focal explanatory variables. However, the model fit of the reduced models reported in Table A8 is worse and suggests that relevant variables are missing.
} 
Radtke, 2014). From that perspective, it is hardly surprising that we could not observe a more marked commitment to participate in energy governance arrangements. However, we were able to observe that RECs are considering becoming (more) active in the future, which holds true both for RECs that are currently exerting influence in subnational governance arrangements and those that indicated (great) dissatisfaction with policy decisions taken at that level.

What are the broader implications of this finding for the European Commission's plea to bring citizens and stakeholders to the core of the Energy Union? Most importantly, the findings suggest that the participation of stakeholders in EU energy governance is being inhibited by barriers, which need to be addressed by the governance arrangements that are still being decided (see Ringel \& Knodt, 2018). Compared to citizen-based groups such as RECs, business interests and energy suppliers are likely to be in a better position to seize the new opportunity structure that the European Commission offers with the Energy Union. It is therefore important to point out to organisations such as RECs that the Energy Union offers them an opportunity structure for participating in governance processes beyond the subnational and national levels.

On the other hand, it was encouraging to see that some German RECs are interested in participating in EU energy governance, even though the great majority of respondents indicated that they prefer to strengthen their activities and engagement at the (sub-)national level. The participation of RECs in energy governance can strengthen their role in attaining low-carbon energy transition (see Cherp, Vinichenko, Jewell, Suzuki, \& Antal, 2017).

Despite the insights offered by this study, we also need to mention its limitations. First, our analysis concentrated on RECs in Germany only, which makes it difficult to draw conclusions for RECs based in other EU member states. A specific feature of RECs in Germany is that, for many years, RECs benefitted from comparatively generous feed-in tariffs and that their recent reduction resulted in significant frustration with policymaking (see Böhringer, Cuntz, Harhoff, \& Asane-Otoo, 2017). A second limitation concerns the small sample size, which forced us to estimate models that contain relatively few explanatory variables. Third, we have crosssectional data only and, considering the changes to renewable energy policy in Germany (most importantly, the reduction of the feed-in tariffs), it would have been useful to have had a dataset at our disposal that dated back to a year before 2014 when the previous regime was still in place.

Despite these limitations, we believe that this study makes a first, and important, contribution towards better understanding the Energy Union's potential for reaching out to a more diverse set of stakeholders and for determining which governance arrangements it can realistically stimulate.

\section{Acknowledgments}

This research received funding from the Field of Focus 4 at Heidelberg University on "Self-Regulation and Regulation: Individuals and Organisations." We are grateful to the participants of the panel "An Energy Union by Policy Surveillance?" at the ECPR General Conference 2018, organised by Michèle Knodt and Jonas Schoenefeld. We acknowledge valuable comments by Andreas Gißler, Prisca Henheik, Jörg Radtke, Adrian Rinscheid and Benjamin Schmid, as well as research assistance by Laurence Crumbie, Manuel Feldmann, Andreas Fleig and Nils Philipp. We thank four anonymous reviewers for their helpful comments and suggestions on a previous version of this manuscript. We acknowledge financial support by Deutsche Forschungsgemeinschaft within the funding programme Open Access Publishing, by the BadenWürttemberg Ministry of Science, Research and the Arts and by Ruprecht-Karls-Universität Heidelberg.

\section{Conflict of Interests}

The authors declare no conflict of interests.

\section{References}

Aklin, M., \& Urpelainen, J. (2018). Renewables: The politics of a global energy transition. Cambridge, MA: MIT Press.

Bazilian, M., Nakhooda, S., \& Van de Graaf, T. (2014). Energy governance and poverty. Energy Research \& Social Science, 1, 217-225.

Böhringer, C., Cuntz, A., Harhoff, D., \& Asane-Otoo, E. (2017). The impact of the German feed-in tariff scheme on innovation: Evidence based on patent filings in renewable energy technologies. Energy Economics, 67, 545-553.

Cherp, A., Jewell, J., \& Goldthau, A. (2011). Governing global energy: Systems, transitions, complexity. Global Policy, 2(1), 75-88.

Cherp, A., Vinichenko, V., Jewell, J., Suzuki, M., \& Antal, M. (2017). Comparing electricity transitions: A historical analysis of nuclear, wind and solar power in Germany and Japan. Energy Policy, 101, 612-628.

Coase, R. H. (1988). The firm, the market, and the law. Chicago, IL: University of Chicago Press.

Dahlman, C. J. (1979). The problem of externality. The Journal of Law and Economics, 22(1), 141-162.

Eising, R. (2007). Institutional context, organizational resources and strategic choices: Explaining interest group access in the European Union. European Union Politics, 8(3), 329-362.

Eising, R. (2008). Interest groups in EU policy-making. Living Reviews in European Governance. Retrieved from http://europeangovernance-livingreviews.org/ Articles/Ireg-2008-4

European Commission. (2015). Communication from the Commission to the European Parliament, the Coun- 
cil, the European Economic and Social Committee, the Committee of the Regions and the European Investment Bank-A framework strategy for a resilient Energy Union with a forward-looking climate change policy (COM/2015/080 final). Brussels: European Commission.

European Commission. (2016a). Communication from the Commission to the European Parliament, the Council, the European Economic and Social Committee, the Committee of the Regions and the European Investment Bank-Clean energy for all Europeans (COM(2016) 860 final). Brussels: European Commission.

European Commission. (2016b). Proposal for a regulation of the European Parliament and of the Council on the Governance of the Energy Union, amending Directive 94/22/EC, Directive 98/70/EC, Directive 2009/31/EC, Regulation (EC) No 663/2009, Regulation (EC) No 715/2009, Directive 2009/73/EC, Council Directive 2009/119/EC, Directive 2010/31/EU, Directive 2012/27/EU, Directive 2013/30/EU and Council Directive (EU) 2015/652 and repealing Regulation (EU) No 525/2013 (COM/2016/0759 final-2016/0375 (COD)). Brussels: European Commission.

European Commission. (2017). Communication from the Commission to the European Parliament, the Council, the European Economic and Social Committee, the Committee of the Regions and the European Investment Bank-Third report on the state of the Energy Union (COM(2017) 688 final). Brussels: European Commission.

European Environment Agency. (2017). Renewable energy in Europe 2017. Recent growth and knock-on effects. Copenhagen: European Environment Agency.

Firth, D. (1993). Bias reduction of maximum likelihood estimates. Biometrika, 80(1), 27-38.

Fischer, B., \& Wetzel, H. (2018). klimaGEN: Entwicklungsdynamik und strukturelle Merkmale von Energiegenossenschaften in Deutschland in den Jahren von 2009 bis 2015 [klimaGEN: Development dynamics and structural characteristics of energy cooperatives in Germany in 2009-2015]. Retrieved from http://www.klimagen.de/fileadmin/user_upload/Kli maGEN_Arbeitspapier_1_web.pdf

Fraune, C., \& Knodt, M. (2017). Challenges of citizen participation in infrastructure policy-making in multi-level systems-The case of onshore wind energy expansion in Germany. European Policy Analysis, 3(2), 256-273.

Fraune, C., \& Knodt, M. (2018). Sustainable energy transformations in an age of populism, post-truth politics, and local resistance. Energy Research \& Social Science, 43, 1-7.

German Cooperative and Raiffeisen Confederation. (2017). Zahlen \& Fakten: DGRV-Die Genossenschaften [Figures \& facts: The DGRV cooperatives]. Retrived from http://dgrv.de/de/ueberuns/ zahlenfakten.html
Hadjar, A., \& Beck, M. (2010). Who does not participate in elections in Europe and why is this? A multilevel analysis of social mechanisms behind non-voting. European Societies, 12(4), 521-542.

Herbes, C., Brummer, V., Rognli, J., Blazejewski, S., \& Gericke, N. (2017). Responding to policy change: New business models for renewable energy cooperatives-Barriers perceived by cooperatives' members. Energy Policy, 109, 82-96.

Holstenkamp, L., \& Kahla, F. (2016). What are community energy companies trying to accomplish? An empirical investigation of investment motives in the German case. Energy Policy, 97, 112-122.

Holyoke, T. T., Brown, H., \& Henig, J. R. (2012). Shopping in the political arena: Strategic state and local venue selection by advocates. State and Local Government Review, 44(1), 9-20.

Huybrechts, B., Creupelandt, D., \& Vansintjan, D. (2018). Networking renewable energy cooperatives-The experience of the European Federation REScoop.eu. In L. Holstenkamp \& J. Radtke (Eds.), Handbuch Energiewende und Partizipation (pp. 847-858). Wiesbaden: Springer VS.

Kahla, F., Holstenkamp, L., Müller, J. R., \& Degenhart, H. (2017). Entwicklung und Stand von Bürgerenergiegesellschaften und Energiegenossenschaften in Deutschland [Development and status of citizens energy cooperatives and energy cooperatives in Germany]. Lüneburg: Leuphana Universität Lüneburg.

Kalkbrenner, B. J., \& Roosen, J. (2016). Citizens' willingness to participate in local renewable energy projects: The role of community and trust in Germany. Energy Research \& Social Science, 13, 60-70.

Klagge, B., \& Meister, T. (2018). Energy cooperatives in Germany-An example of successful alternative economies? Local Environment, 23(7), 697-716.

Marcinkiewicz, K., \& Tosun, J. (2015). Contesting climate change: Mapping the political debate in Poland. East European Politics, 31(2), 187-207.

Moss, T., Becker, S., \& Naumann, M. (2015). Whose energy transition is it, anyway? Organisation and ownership of the Energiewende in villages, cities and regions. Local Environment, 20(12), 1547-1563.

Müller, J. R., Dorniok, D., Flieger, B., Holstenkamp, L., Mey, F., \& Radtke, J. (2015). Energiegenossenschaften-Das Erfolgsmodell braucht neue Dynamik [Energy cooperatives: The success model needs new dynamics]. GAIA, 24(2), 96-101.

North, D. C. (1992). Transaction costs, institutions, and economic performance. San Francisco, CA: ICS Press.

Pierson, P. (2000). Increasing returns, path dependence, and the study of politics. The American Political Science Review, 94(2), 251-267.

Pleines, H. (2010). Is this the way to Brussels? CEE civil society involvement in EU governance. Acta Politica, 45(1/2), 229-246.

Princen, S., \& Keremas, B. (2008). Opportunity structures in the EU multi-level system. West European Politics, 
31(6), 1129-1146.

Radtke, J. (2014). A closer look inside collaborative action: Civic engagement and participation in community energy initiatives. People, Place \& Policy Online, 8(3), 235-248.

Ringel, M., \& Knodt, M. (2018). The governance of the European Energy Union: Efficiency, effectiveness and acceptance of the Winter Package 2016. Energy Policy, 112, 209-220.

Scherhaufer, P., Höltinger, S., Salak, B., Schauppenlehner, T., \& Schmidt, J. (2017). Patterns of acceptance and non-acceptance within energy landscapes: A case study on wind energy expansion in Austria. Energy Policy, 109, 863-870.

Szulecki, K., Fischer, S., Gullberg, A. T., \& Sartor, O. (2016). Shaping the 'Energy Union': Between national positions and governance innovation in EU energy and climate policy. Climate Policy, 16(5), 548-567.

Thelen, K. (1999). Historical institutionalism in comparative politics. Annual Review of Political Science, 2(1), 369-404.

Tosun, J., Biesenbender, S., \& Schulze, K. (2015). Building the EU's energy policy agenda: An introduction.
In J. Tosun, S. Biesenbender, \& K. Schulze (Eds.), Energy policy making in the EU-Building the agenda (pp. 1-17). London: Springer.

Tosun, J., De Francesco, F., \& Peters, B. G. (2018). From environmental policy concepts to practicable tools: Knowledge creation and delegation in multilevel systems. Public Administration. doi:10.1111/ padm.12544

Unnerstall, T. (2017). The German energy transition: Design, implementation, cost and lessons. Berlin: Springer.

Verbong, G., \& Loorbach, D. (2012). Governing the energy transition: Reality, illusion or necessity? London: Routledge.

Williamson, O. E. (1981). The economics of organization: The transaction cost approach. American Journal of Sociology, 87(3), 548-577.

Yildiz, Ö., Rommel, J., Debor, S., Holstenkamp, L., Mey, F., Müller, J. R., . . Rognli, J. (2015). Renewable energy cooperatives as gatekeepers or facilitators? Recent developments in Germany and a multidisciplinary research agenda. Energy Research \& Social Science, 6, 59-73.

\section{About the Authors}
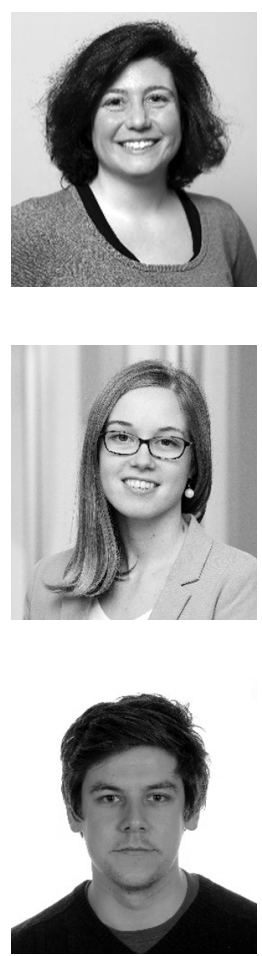

Jale Tosun is Professor of Political Science at Heidelberg University and a Co-Director of the Heidelberg Center for the Environment. Her research interests comprise various topics in comparative public policy, comparative politics, international political economy, public administration and European studies.

Laura Zöckler holds a BA in Political Science and completed her MA in Political Science at Heidelberg University in February 2018. She worked with Jale Tosun as a research assistant on energy and environmental policy and wrote her master's thesis on German Renewable Energy Cooperatives (RECs). Currently, she works at Bürgerwerke eG, a network of RECs supplying renewable energy, and serves as an Executive Board member at Heidelberger Energiegenossenschaft eG.

Benedikt Rilling is a doctoral student at the Institute of Political Science at the Heidelberg University and research associate at the Nuertingen-Geislingen University. His research focuses on Renewable Energy Cooperatives with a dedicated focus on their managers and future business models. He completed a MSc in Human Geography at the LMU Munich and holds a BA in Socioeconomics. 
Annex

Table A3. Wording of the questions from the online survey (translated from German).

\begin{tabular}{|c|c|c|}
\hline Variable & Wording of question in online survey & Coding \\
\hline \multicolumn{3}{|l|}{ Outcome variables } \\
\hline Subnational Future & $\begin{array}{l}\text { Which political level is your cooperative } \\
\text { intending to influence in the future? } \\
\text { [community; regional] }\end{array}$ & Binary variable (yes $=1 ;$ no $=0$ ) \\
\hline National Future & $\begin{array}{l}\text { Which political level is your cooperative } \\
\text { intending to influence in the future? } \\
\text { [federal] }\end{array}$ & Binary variable (yes $=1 ;$ no $=0$ ) \\
\hline EU/transnational Future & $\begin{array}{l}\text { Which political level is your cooperative } \\
\text { intending to influence in the future? } \\
\text { [European; transnational] }\end{array}$ & Binary variable (yes $=1 ;$ no $=0$ ) \\
\hline \multicolumn{3}{|l|}{ Focal explanatory variables } \\
\hline Subnational Current & $\begin{array}{l}\text { Which political level is your cooperative } \\
\text { currently influencing? } \\
\text { [community; regional] }\end{array}$ & Binary variable (yes $=1 ;$ no $=0$ ) \\
\hline National Current & $\begin{array}{l}\text { Which political level is your cooperative } \\
\text { currently influencing? } \\
\text { [federal] }\end{array}$ & Binary variable (yes $=1 ;$ no $=0$ ) \\
\hline EU/transnational Current & $\begin{array}{l}\text { Which political level is your cooperative } \\
\text { currently influencing? } \\
\text { [European; transnational] }\end{array}$ & Binary variable (yes $=1 ;$ no $=0$ ) \\
\hline Subnational Dissatisfaction & $\begin{array}{l}\text { How satisfied are you with energy policy } \\
\text { on different political levels? } \\
\text { [community; regional] }\end{array}$ & $\begin{array}{l}4 \text { (= very unsatisfied) to } 1 \text { (= very } \\
\text { satisfied); mean value of dissatisfaction } \\
\text { with the community and regional level }\end{array}$ \\
\hline National Dissatisfaction & $\begin{array}{l}\text { How satisfied are you with energy } \\
\text { policy on different political levels? } \\
\text { [federal] }\end{array}$ & $\begin{array}{l}4 \text { (= very unsatisfied) to } \\
1 \text { (= very satisfied) }\end{array}$ \\
\hline EU Dissatisfaction & $\begin{array}{l}\text { How satisfied are you with energy policy } \\
\text { on different political levels? } \\
\text { [EU] }\end{array}$ & $\begin{array}{l}4 \text { (= very unsatisfied) to } \\
1 \text { (= very satisfied) }\end{array}$ \\
\hline \multicolumn{3}{|l|}{ Control variables } \\
\hline Age & $\begin{array}{l}\text { When was your cooperative founded? } \\
\text { Please state the year. }\end{array}$ & Reference year $=2017$ \\
\hline Membership & $\begin{array}{l}\text { How many members has your cooperative } \\
\text { currently? Please state the quantity. }\end{array}$ & $\begin{array}{l}8 \text { categories; } 1=\text { smaller than } 50 \text { to } \\
8=\text { greater than } 1000\end{array}$ \\
\hline Political engagement & $\begin{array}{l}\text { Does your cooperation follow political } \\
\text { decisions regarding energy policy? }\end{array}$ & Binary variable (yes $=1 ;$ no $=0$ ) \\
\hline Political ambition & $\begin{array}{l}\text { What of these before mentioned aims of } \\
\text { your cooperative is the most important aim? } \\
\text { [Political] }\end{array}$ & Binary variable (yes $=1 ;$ no $=0$ ) \\
\hline Investment & $\begin{array}{l}\text { How much money has your cooperative } \\
\text { invested in energy transformation projects } \\
\text { so far? Please state the approximate volume } \\
\text { in EUR. }\end{array}$ & $\begin{array}{l}4 \text { categories; } 1 \text { = below } 200.000 \text { EUR to } \\
4=\text { above } 3 \text { million EUR }\end{array}$ \\
\hline
\end{tabular}


Table A6. Results of the logistic regression models for the three outcomes variables and total level of future influence as a fourth outcome variable.

\begin{tabular}{|c|c|c|c|c|c|c|c|c|}
\hline & Sub-Basic & Sub-Full & Nat-Basic & Nat-Full & EU-Basic & EU-Full & Tot-Basic & Tot-Full \\
\hline $\begin{array}{l}\text { Subnational } \\
\text { Current }\end{array}$ & $\begin{array}{l}64.74 \\
(54.46) * * *\end{array}$ & $\begin{array}{l}64.43 \\
(59.92) * * *\end{array}$ & & & & & & \\
\hline $\begin{array}{l}\text { National } \\
\text { Current }\end{array}$ & & & $\begin{array}{l}36.98 \\
(28.50)^{* * *}\end{array}$ & $\begin{array}{l}49.76 \\
(41.80)^{* * *}\end{array}$ & & & & \\
\hline $\begin{array}{l}\text { EU/transnational } \\
\text { Current }\end{array}$ & & & & & $\begin{array}{l}74.15 \\
(64.79) * * *\end{array}$ & $\begin{array}{l}71.12 \\
(67.48)^{* * *}\end{array}$ & & \\
\hline Current & & & & & & & $\begin{array}{l}58.42 \\
(48.80)^{* * *}\end{array}$ & $\begin{array}{l}65.60 \\
(60.66)^{* * *}\end{array}$ \\
\hline $\begin{array}{l}\text { Subnational } \\
\text { Dissatisfaction }\end{array}$ & $\begin{array}{l}3.72 \\
(1.94)^{* *}\end{array}$ & $\begin{array}{l}3.49 \\
(1.95)^{* *}\end{array}$ & $\begin{array}{l}1.14 \\
(0.37)\end{array}$ & $\begin{array}{l}1.46 \\
(0.54)\end{array}$ & $\begin{array}{l}1.46 \\
(0.52)\end{array}$ & $\begin{array}{l}1.62 \\
(0.65)\end{array}$ & $\begin{array}{l}3.17 \\
(1.60)^{* *}\end{array}$ & $\begin{array}{l}3.42 \\
(1.90)^{* *}\end{array}$ \\
\hline $\begin{array}{l}\text { National } \\
\text { Dissatisfaction }\end{array}$ & $\begin{array}{l}1.39 \\
(0.84)\end{array}$ & $\begin{array}{l}1.28 \\
(0.83)\end{array}$ & $\begin{array}{l}1.55 \\
(0.68)\end{array}$ & $\begin{array}{l}2.18 \\
(1.10)\end{array}$ & $\begin{array}{l}0.93 \\
(0.46)\end{array}$ & $\begin{array}{l}1.09 \\
(0.58)\end{array}$ & $\begin{array}{l}1.70 \\
(1.05)\end{array}$ & $\begin{array}{l}1.20 \\
(0.79)\end{array}$ \\
\hline $\begin{array}{l}\text { EU } \\
\text { Dissatisfaction }\end{array}$ & $\begin{array}{l}0.76 \\
(0.47) \\
\end{array}$ & $\begin{array}{l}0.83 \\
(0.55) \\
\end{array}$ & $\begin{array}{l}0.83 \\
(0.35) \\
\end{array}$ & $\begin{array}{l}0.78 \\
(0.36) \\
\end{array}$ & $\begin{array}{l}1.31 \\
(0.63) \\
\end{array}$ & $\begin{array}{l}1.22 \\
(0.58) \\
\end{array}$ & $\begin{array}{l}0.64 \\
(0.41) \\
\end{array}$ & $\begin{array}{l}0.88 \\
(0.58) \\
\end{array}$ \\
\hline Age & & $\begin{array}{l}1.18 \\
(0.20)\end{array}$ & & $\begin{array}{l}0.93 \\
(0.12)\end{array}$ & & $\begin{array}{l}0.88 \\
(0.12)\end{array}$ & & $\begin{array}{l}1.18 \\
(0.19)\end{array}$ \\
\hline Membership & & $\begin{array}{l}0.93 \\
(0.25) \\
\end{array}$ & & $\begin{array}{l}0.73 \\
(0.14)^{*}\end{array}$ & & $\begin{array}{l}0.74 \\
(0.15) \\
\end{array}$ & & $\begin{array}{l}0.92 \\
(0.25) \\
\end{array}$ \\
\hline Investment & & $\begin{array}{l}0.85 \\
(0.32)\end{array}$ & & $\begin{array}{l}2.30 \\
(0.74)^{* * *}\end{array}$ & & $\begin{array}{l}1.50 \\
(0.45)\end{array}$ & & $\begin{array}{l}0.87 \\
(0.33)\end{array}$ \\
\hline $\begin{array}{l}\text { Political } \\
\text { Engagement }\end{array}$ & & $\begin{array}{l}1.12 \\
(1.10) \\
\end{array}$ & & $\begin{array}{l}3.56 \\
(4.39) \\
\end{array}$ & & $\begin{array}{l}3.05 \\
(4.52) \\
\end{array}$ & & $\begin{array}{l}1.08 \\
(1.05) \\
\end{array}$ \\
\hline $\begin{array}{l}\text { Political } \\
\text { Ambition }\end{array}$ & & - & & $\begin{array}{l}1.90 \\
(1.94)\end{array}$ & & $\begin{array}{l}0.63 \\
(0.80)\end{array}$ & & - \\
\hline Cases & 154 & 140 & 123 & 121 & 154 & 151 & 154 & 140 \\
\hline $\mathrm{AIC}$ & 76.97 & 82.01 & 129.94 & 129.09 & 109.59 & 103.62 & 76.73 & 81.46 \\
\hline
\end{tabular}

Notes: The table reports odds ratios; the models for the EU are estimated with the Firth correction; in Model Sub-Full and Model Tot-Full, the odds ratios for political ambition are omitted from the estimation routine because of this variable's dependence on other variables in the model. $* p<0.10, * * p<0.05 ; * * p<0.01$. 
Table A7. Results of the logistic regression models without the first set of focal explanatory variables.

\begin{tabular}{|c|c|c|c|c|c|c|c|c|}
\hline & Sub-Basic & Sub-Full & Nat-Basic & Nat-Full & EU-Basic & EU-Full & Tot-Basic & Tot-Full \\
\hline Subnational Dissatisfaction & $\begin{array}{l}2.65 \\
(1.02)^{* *}\end{array}$ & $\begin{array}{l}2.14 \\
(0.89)^{*}\end{array}$ & $\begin{array}{l}1.59 \\
(0.41)^{*}\end{array}$ & $\begin{array}{l}1.75 \\
(0.51)^{*}\end{array}$ & $\begin{array}{l}1.70 \\
(0.46)^{* *}\end{array}$ & $\begin{array}{l}1.87 \\
(0.57)^{* *}\end{array}$ & $\begin{array}{l}2.51 \\
(0.97)^{* *}\end{array}$ & $\begin{array}{l}2.14 \\
(0.89)^{*}\end{array}$ \\
\hline National Dissatisfaction & $\begin{array}{l}1.20 \\
(0.52)\end{array}$ & $\begin{array}{l}1.36 \\
(0.69)\end{array}$ & $\begin{array}{l}1.59 \\
(0.55)\end{array}$ & $\begin{array}{l}1.88 \\
(0.72)^{*}\end{array}$ & $\begin{array}{l}0.93 \\
(0.35)\end{array}$ & $\begin{array}{l}1.13 \\
(0.45)\end{array}$ & $\begin{array}{l}1.38 \\
(0.61)\end{array}$ & $\begin{array}{l}1.36 \\
(0.69)\end{array}$ \\
\hline EU Dissatisfaction & $\begin{array}{l}1.37 \\
(0.61)\end{array}$ & $\begin{array}{l}1.25 \\
(0.62)\end{array}$ & $\begin{array}{l}1.05 \\
(0.36)\end{array}$ & $\begin{array}{l}1.09 \\
(0.40)\end{array}$ & $\begin{array}{l}1.38 \\
(0.51)\end{array}$ & $\begin{array}{l}1.23 \\
(0.45)\end{array}$ & $\begin{array}{l}1.21 \\
(0.55)\end{array}$ & $\begin{array}{l}1.25 \\
(0.62)\end{array}$ \\
\hline Age & & $\begin{array}{l}1.09 \\
(0.12)\end{array}$ & & $\begin{array}{l}1.10 \\
(0.10)\end{array}$ & & $\begin{array}{l}0.99 \\
(0.08)\end{array}$ & & $\begin{array}{l}1.09 \\
(0.12)\end{array}$ \\
\hline Membership & & $\begin{array}{l}1.17 \\
(0.22)\end{array}$ & & $\begin{array}{l}0.85 \\
(0.13)\end{array}$ & & $\begin{array}{l}0.77 \\
(0.12)\end{array}$ & & $\begin{array}{l}1.17 \\
(0.22)\end{array}$ \\
\hline Investment & & $\begin{array}{l}0.73 \\
(0.22)\end{array}$ & & $\begin{array}{l}1.55 \\
(0.37)^{*}\end{array}$ & & $\begin{array}{l}1.49 \\
(0.37) \\
\end{array}$ & & $\begin{array}{l}0.73 \\
(0.22)\end{array}$ \\
\hline Political Engagement & & $\begin{array}{l}8.55 \\
(7.17)^{* *}\end{array}$ & & $\begin{array}{l}4.07 \\
(3.73)\end{array}$ & & $\begin{array}{l}6.77 \\
(10.00)\end{array}$ & & $\begin{array}{l}8.55 \\
(7.17)^{* *}\end{array}$ \\
\hline Political Ambition & & - & (2.79) & 3.57 & (1.29) & 1.83 & & - \\
\hline Cases & 154 & 140 & 129 & 127 & 154 & 151 & 154 & 140 \\
\hline AIC & 120.97 & 115.04 & 179.32 & 176.82 & 161.70 & 149.82 & 117.97 & 115.04 \\
\hline
\end{tabular}

Notes: The table reports odds ratios; the models for the EU are estimated with the Firth correction; in Model Sub-Full and Model Tot-Full, the odds ratios for political ambition are omitted from the estimation routine because of this variable's dependence on other variables in the model. ${ }^{*} \mathrm{p}<0.10,{ }^{* *} \mathrm{p}<0.05 ;{ }^{* * *} \mathrm{p}<0.01$.

Table A8. Results of the logistic regression models without the first set of focal explanatory variables and a reduced set of variables for dissatisfaction.

\begin{tabular}{|c|c|c|c|c|c|c|c|c|}
\hline & Sub-Basic & Sub-Full & Nat-Basic & Nat-Full & EU-Basic & EU-Full & Tot-Basic & Tot-Full \\
\hline Subnational Dissatisfaction & $\begin{array}{l}2.80 \\
(1.03)^{* * *}\end{array}$ & $\begin{array}{l}2.39 \\
(0.93)^{* *}\end{array}$ & & & & & $\begin{array}{l}2.51 \\
(0.97)^{* *}\end{array}$ & $\begin{array}{l}2.14 \\
(0.89)^{*}\end{array}$ \\
\hline National Dissatisfaction & & & $\begin{array}{l}1.97 \\
(0.53)^{* *}\end{array}$ & $\begin{array}{l}2.35 \\
(0.68)^{* * *}\end{array}$ & & & $\begin{array}{l}1.38 \\
(0.61)\end{array}$ & $\begin{array}{l}1.36 \\
(0.69)\end{array}$ \\
\hline EU Dissatisfaction & & & & & $\begin{array}{l}1.46 \\
(0.44)\end{array}$ & $\begin{array}{l}1.41 \\
(0.42)\end{array}$ & $\begin{array}{l}1.21 \\
(0.55)\end{array}$ & $\begin{array}{l}1.25 \\
(0.62)\end{array}$ \\
\hline Age & & $\begin{array}{l}1.08 \\
(0.11)\end{array}$ & & $\begin{array}{l}1.11 \\
(0.10)\end{array}$ & & $\begin{array}{l}0.99 \\
(0.08)\end{array}$ & & $\begin{array}{l}1.09 \\
(0.12)\end{array}$ \\
\hline Membership & & $\begin{array}{l}1.22 \\
(0.21)\end{array}$ & & $\begin{array}{l}0.95 \\
(0.12)\end{array}$ & & $\begin{array}{l}0.86 \\
(0.12)\end{array}$ & & $\begin{array}{l}1.17 \\
(0.22)\end{array}$ \\
\hline Investment & & $\begin{array}{l}0.64 \\
(0.18)\end{array}$ & & $\begin{array}{l}1.37 \\
(0.29)\end{array}$ & & $\begin{array}{l}1.21 \\
(0.26)\end{array}$ & & $\begin{array}{l}0.73 \\
(0.22)\end{array}$ \\
\hline Political Engagement & & $\begin{array}{l}5.59 \\
(4.18)^{* *}\end{array}$ & & $\begin{array}{l}5.98 \\
(5.23)^{* *}\end{array}$ & & $\begin{array}{l}6.37 \\
(9.30)\end{array}$ & & $\begin{array}{l}8.55 \\
(7.17)^{* *}\end{array}$ \\
\hline Political Ambition & & $\begin{array}{l}2.20 \\
(2.49)\end{array}$ & & $\begin{array}{l}3.17 \\
(2.25)\end{array}$ & & $\begin{array}{l}1.58 \\
(1.09)\end{array}$ & & - \\
\hline Cases & 171 & 168 & 140 & 138 & 156 & 153 & 154 & 140 \\
\hline AIC & 130.14 & 128.78 & 190.88 & 186.80 & 167.45 & 156.26 & 117.97 & 115.04 \\
\hline
\end{tabular}

Notes: The table reports odds ratios; the models for the EU are estimated with the Firth correction; in Model Tot-Full, the odds ratios for political ambition are omitted from the estimation routine because of this variable's dependence on other variables in the model. $* p<0.10, * * p<0.05 ; * * *<0.01$. 